\title{
PĄKI, LIŚCIE I NASIONA PORZECZKI CZARNEJ - ŹRÓDLO SUBSTANCJI BIOAKTYWNYCH O PROZDROWOTNYCH WŁAŚCIWOŚCIACH
}

\author{
Streszczenie
}

Porzeczka czarna jest rośliną uprawianą ze względu na smaczne owoce, które spożywa się w formie świeżej i przetworzonej. Owoce są cennym składnikiem diety ze względu na dużą zawartość związków o działaniu prozdrowotnym, jak: witamina $\mathrm{C}$, związki fenolowe, składniki mineralne. Pąki, liście i nasiona porzeczki czarnej to mało znane źródło związków bioaktywnych o właściwościach prozdrowotnych i leczniczych. W tradycyjnej medycynie wykorzystuje się pąki, liście i nasiona porzeczki w leczeniu niektórych chorób. Współczesne badania naukowe potwierdzają korzystne działanie tych dotychczas niedocenianych części rośliny porzeczki czarnej. Głównymi związkami bioaktywnymi zawartymi w pąkach porzeczki czarnej są olejki eteryczne, w tym węglowodory i terpeny. Olejki z pąków charakteryzują się silną aktywnością przeciwbakteryjną i przeciwgrzybową. Kolejną grupą substancji bioaktywnych są związki fenolowe, wśród których występują głownie rutyna, epikatechiny i kemferole. Substancje te nadają pąkom właściwości przeciwutleniające i przeciwzapalne. Olej z nasion porzeczki czarnej może być dobrym źródłem nienasyconych kwasów tłuszczowych i tokoferoli, zwłaszcza $\alpha$-tokoferolu. Występują w nim także sterole znane z przeciwmiażdżycowej i przeciwnowotworowej aktywności Wyciągi z nasion czarnej porzeczki zawierają dużo pożądanych składników biologicznie aktywnych, jak związki fenolowe i polisacharydy, głównie galaktany. Ekstrakty z liści ze względu na dużą zawartość różnorodnych związków fenolowych i olejków eterycznych mają właściwości przeciwutleniające. Liście porzeczki czarnej mają unikatowy skład kwasów tłuszczowych o potencjalnej aktywności przeciwnowotworowej, przeciwzapalnej i przeciwdrobnoustrojowej. W liściach stosunek zawartości potasu do sodu jest wysoki, co wyjaśnia moczopędne działanie naparów z liści. W pracy podano przykłady zastosowania pąków, nasion i liści. Celem publikacji było usystematyzowanie wiedzy o prozdrowotnych zastosowaniach ekstraktów z tych surowców.

Dr hab. A. Krzepiłko, prof. nadzw., Katedra Biotechnologii, Mikrobiologii i Żywienia Człowieka, Wydz. Nauk o Żywności i Biotechnologii, Uniwersytet Przyrodniczy w Lublinie, ul. Skromna 8, 20-704 Lublin, dr hab. R. Prażak, Instytut Genetyki, Hodowli i Biotechnologii Roślin, Wydz. Agrobioinżynierii, Uniwersytet Przyrodniczy w Lublinie, ul. Akademicka 15, 20-950 Lublin, dr hab. B. Skwaryło-Bednarz, Zakład Metod Ochrony Roślin, Katedra Ochrony Roślin, Wydz. Ogrodnictwa i Architektury Krajobrazu, dr A. Święciło, Katedra Mikrobiologii Środowiskowej, Wydz. Agrobioinżynierii, Uniwersytet Przyrodniczyw Lublinie, ul. Leszczyńskiego 7,20-069 Lublin. Kontakt: anna.krzepilko@up.lublin.pl 
Słowa kluczowe: porzeczka czarna, pąki, nasiona, liście, związki bioaktywne

\section{Wprowadzenie}

Porzeczka czarna (Ribes nigrum L.) pochodzi z obszarów Europy i Azji o umiarkowanym klimacie. Światowa produkcja czarnych porzeczek według International Blackcurrant Association wynosi $177 \div 225$ tys. ton rocznie. Polska z produkcją ok. $110 \div 150$ tys. ton rocznie jest liderem i niezależnie od roku owoce czarnej porzeczki stanowią ponad $55 \%$ światowej produkcji [34]. Owoce te są wartościowym składnikiem diety, są niskokaloryczne, bogate w substancje bioaktywne i składniki mineralne [15]. Zawierają łatwo przyswajalne cukry, stosunkowo dużo kwasów organicznych, jak: cytrynowy, jabłkowy, bursztynowy, salicylowy, pektyny, związki: fosforu, potasu, wapnia, magnezu, żelaza, manganu, sodu, boru, jodu i witaminy: A, B, C, K, PP [16]. Znaczne ilości antocyjanów, które są nagromadzone przede wszystkim w skórce, nadają dojrzałym jagodom intensywną ciemną barwę. W porzeczkach czarnych stężenie związków fenolowych, w tym antocyjanów i innych flawonoidów, jest znacznie wyższe niż w wielu innych owocach. Większość publikacji na temat prozdrowotnych właściwości czarnej porzeczki dotyczy surowych owoców i różnych produktów z nich otrzymywanych. Bogactwo składników sprawia, że owoce i ich przetwory mają wielorakie działanie prozdrowotne. Spożywane są głównie w celu wzmocnienie układu odpornościowego, zmniejszenia ryzyka otyłości i zmniejszenia ryzyka przewlekłych chorób dietozależnych, np. chorób układu krążenia, cukrzycy [33]. Owoce czarnej porzeczki wykazują silne działanie przeciwzapalne, przeciwutleniające i przeciwdrobnoustrojowe. Wyniki badań in vivo wskazują na terapeutyczny potencjał produktów z owoców czarnej porzeczki w odniesieniu do nadciśnienia tętniczego i innych chorób związanych z układem krążenia, kamicy nerkowej, neuropatii cukrzycowej, nowotworów i chorób neurodegeneracyjnych [13]. Prozdrowotne działanie owoców czarnej porzeczki związane jest z występowaniem w nich związków o działaniu przeciwutleniającym, które obniżają stres oksydacyjny powodowany przez wolne rodniki tlenowe, stymulują aktywność enzymów odpowiedzialnych za ich usuwanie (dysmutazy ponadtlenkowej i peroksydazy glutationowej) i przeciwdziałają oksydacyjnym modyfikacjom cząsteczek budujących komórki (DNA, lipidy, białka) [14]. Dzięki dużej zawartości przeciwutleniaczy ekstrakty $\mathrm{z}$ owoców mogą być pomocne $\mathrm{w}$ zapobieganiu i leczeniu chorób o wolnorodnikowej etiologii oraz chorób nowotworowych [22]. Ekstrakty z owoców czarnej porzeczki mają także działanie przeciwwirusowe [27]. Zawartość składników prozdrowotnych w porzeczce czarnej w znacznym stopniu zależy od genotypu, chociaż wpływ na nią mają również warunki wzrostu [16]. Analiza składu chemicznego liści, pąków i nasion porzeczki czarnej potwierdziła, że podobnie jak owoce, także i te części rośliny zawierają cenne składniki i mogą być źródłem bioak- 
tywnych produktów naturalnych wykorzystywanych $\mathrm{w}$ codziennej diecie, produkcji nutraceutyków, żywności funkcjonalnej, kosmetyków [17, 20, 26, 28]. Wiedza na temat składu i prozdrowotnych efektów wywieranych przez bioaktywne substancje zawarte w nasionach, liściach i pąkach nie jest tak powszechna jak znajomość właściwości owoców.

Celem pracy był przegląd literatury i usystematyzowanie wiedzy na temat składu chemicznego i oddziaływania pąków, liści i nasion porzeczki czarnej na organizm człowieka oraz omówienie możliwości ich zastosowania.

\section{Pąki porzeczki czarnej (Ribis nigri folliculos germinaret) - skladniki bioaktywne i zastosowanie}

Pąki roślin dla celów terapeutycznych stosowano już w starożytności w Indiach w medycynie ajurwedyjskiej i w Europie w Grecji, a w średniowieczu przez Paracelsusa. W połowie XX wieku zaczęła się rozwijać gemmoterapia - dział fitoterapii wykorzystujący części roślin zawierające tkanki merystematyczne, w tym pąki liściowokwiatowe. W pąkach zawarta jest większa różnorodność i ilość substancji czynnych niż we w pełni ukształtowanych częściach rośliny [7].

Pąki porzeczki czarnej gromadzą olejki eteryczne, uwalniają lotne związki aromatyczne o silnie terpenowym zapachu. W oleju uzyskiwanym z pąków czarnej porzeczki zidentyfikowano ok. pięćdziesięciu lotnych związków. W składzie przeważały węglowodory $(38 \div 55 \%$ ) i utlenione terpeny (ok. $30 \%$ ) [8]. Substancje występujące w najwyższych stężeniach to: $\alpha$-pinen $(1,6 \div 5,4 \%)$, sabinen $(1,9 \div 38,4 \%), \delta$-3-karan $(13,0$ $\div 50,7 \%)$, $\beta$-fellandren $(2,9 \div 18,0 \%)$, terpinolen $(6,6 \div 11,9 \%)$, terpinen-4-ol $(0,9 \div$ $6,6 \%), \beta$-kariofillen $(3,8 \div 10,4 \%)$, i $\alpha$-humulen $(0,2 \div 4,1 \%)$ [9].

Najlepszą porą zbioru pąków jest okres późnej zimy i wczesnej wiosny, a oleje o największej zawartości terpenów pozyskiwano $\mathrm{z}$ materiału zebranego w styczniu. W kwietniu wraz z rozwojem pąków ilość składników aromatycznych zmniejszała się od 2 do nawet 50 razy w porównaniu z innymi okresami zbioru (grudzień - kwiecień). Olejki eteryczne z pąków porzeczki czarnej miały bardzo silne działanie hamujące wzrost mikroorganizmów, ograniczały wzrost bakterii Acinetobacter, Escherichia coli, Pseudomonas aeruginoasa i Staphylococcus aureus [24]. Ethordević i wsp. [9] potwierdzili te obserwacje - olejki eteryczne z pąków porzeczki czarnej uzyskane w wyniku destylacji z parą wodną charakteryzowały się szerokim spektrum aktywności przeciwbakteryjnej i przeciwgrzybowej. Grzyby były bardziej wrażliwe niż bakterie, gdyż ich wzrost hamowany był całkowicie przy znacznie niższych stężeniach olejków eterycznych. Do całkowitego zahamowania przyrostu grzybni zastosowano znacznie niższe stężenia olejków w porównaniu z komercyjnymi antybiotykami [9]. Olejki eteryczne $\mathrm{z}$ pąków $\mathrm{w}$ stanie uśpienia zbierane $\mathrm{w}$ marcu są także stosowane $\mathrm{w}$ przemyśle kosmetycznymi jako substancje wzmacniające aromat i składnik perfum [25]. 
Pąki porzeczki czarnej są bogatym źródłem polifenoli [30]. Nabrzmiałe pąki zebrane $\mathrm{w}$ marcu zawierały najwięcej związków polifenolowych. Spośród wykrytych substancji w wysokich stężeniach występowały (-)epikatechina, rutyna, 3-O-glukozyd kemferolu, 3-O-glukozyd izoramnetyny, 3- $\beta$-D-O-glukozyd kwercetyny, kwercetyna i kwas chlorogenowy. Spośród wymienionych substancji fenolowych w pąkach dominowały rutyna, epikatechiny i kemferole, zaś zawartość kwasu chlorogenowego była bardzo mała przez cały sezon wegetacji. Tabart [28] porównał zdolności przeciwutleniające pąków, liści oraz owoców czarnej porzeczki i potwierdził, że pąki zawierały więcej polifenoli i innych przeciwutleniaczy niż dojrzałe jagody.

$\mathrm{W}$ medycynie naturalnej pąki z porzeczki czarnej stosowano w leczeniu chorób zakaźnych [13]. W badaniach naukowych potwierdzono przeciwbakteryjne działanie ekstraktów z pąków i młodych pędów w stosunku do szczepów Staphylococcus aureus, Escherichia coli, Pseudomonas aeruginosa i Bacillus subtilis, a także przeciwgrzybowe wobec Aspergillus niger i Candida albicans [24]. Substancje zawarte w pąkach mają działanie przeciwzapalne. Wyciąg z pąków porzeczki czarnej stosowano przez trzy miesiące u trzydziestu pacjentów z reumatoidalnym zapaleniem stawów. Stan ich zdrowia poprawił się tak, że można było zmniejszyć dawki niesteroidowych leków przeciwzapalnych [19].

\section{Nasiona porzeczki czarnej (Ribis nigri semina)}

Nasiona porzeczki czarnej są głównym produktem ubocznym powstającym podczas produkcji soku. Zawierają one średnio $20,3 \%$ białka oraz 14,8 \% tłuszczu, 55,8 \% sacharydów, 1,6\% popiołu [23].

Olej z nasion porzeczki czarnej zawiera dużo pożądanych składników odżywczych, jak: kwas $\gamma$-linolenowy, kwas $\alpha$-linolenowy i kwas stearydynowy [18:4(n-3)]. Całkowita zawartość kwasów tłuszczowych zależy od genotypu porzeczki czarnej i wynosi $14 \div 23 \%$ suchej masy nasion [25]. Zawartość kwasu $\gamma$-linolenowego wynosi $11 \div 19 \%$ całkowitej ilości kwasów tłuszczowych, kwasu stearydynowego $-2 \div 4 \%$, zaś kwasu $\alpha$-linolenowego $-10 \div 19 \%$. Kwasy thuszczowe nienasycone powinny być stałym elementem diety człowieka, dlatego olej z nasion porzeczki czarnej może być ich doskonałym źródłem. Na uwagę zasługują korzystne proporcje zawartości kwasów n-6 i $n$-3 wynoszące jak $4: 1$ [32]. Porównano wpływ suplementacji olejem z nasion porzeczki i olejem rybnym na lipidogram kobiet. Suplementację prowadzono codziennie w dwóch czterotygodniowych cyklach w ilości $3 \mathrm{~g}$ oleju z porzeczek lub 2,8 g oleju rybnego. Spożywanie oleju z nasion czarnej porzeczki spowodowało korzystne zmiany lipidogramu. W puli triacylogliceroli i estrów cholesterolu wzrósł odsetek kwasów tłuszczowych 18:3n6, glicerofosfolipidy zawierały więcej kwasu dihomo-gamma linolenowego (20:3n6). Olej z nasion porzeczki czarnej spowodował tylko niewielkie zmiany w proporcjach kwasów thuszczowych: eikozapentaenowego (20:5n3) i dokoza- 
heksaenowego (22:6n3). Również po suplementacji olejem z nasion porzeczki czarnej obniżało się stężenie cholesterolu LDL we krwi [29].

Olej z nasion porzeczki czarnej jest także bogatym źródłem tokoferoli (średnio $1716 \mathrm{mg} \mathrm{kg}^{-1}$ oleju). Zawartość tokoferolu jest zbliżona do olejów otrzymywanych z kiełków pszenicy i kukurydzy, które obecnie są najważniejszym źródłem naturalnej witaminy E. W oleju z nasion porzeczki czarnej w puli tokoferoli występuje aż 34,8 \% najbardziej aktywnego biologicznie $\alpha$-tokoferolu [12]. Występują w nim także sterole w ilości ok. $6,5 \mathrm{~g} \cdot 100 \mathrm{~g}^{-1}$ oleju, znane z przeciwmiażdżycowej i przeciwnowotworowej aktywności [1]. W grupie biologicznie aktywnych składników oleju z nasion porzeczki znajdują się także związki fenolowe. Ogólna zawartość związków fenolowych wynosi średnio $340 \mathrm{mg}$ na $100 \mathrm{~g}$ pestek porzeczki czarnej [23]. Związki fenolowe działają jako naturalne przeciwutleniacze. W oleju z nasion porzeczki czarnej występują antocyjany: 3-O-rutynozyd delfinidyny, 3-O-glukozyd delfinidyny, 3-O-rutynozyd cyanidyny i 3-O-glukozyd cyanidyny. Wykryto też flawonoidy: 3-O-rutynozyd mirycetyny, 3-O-glukozyd mirycetyny, 3-O-rutynozyd kwercetyny, 3-O-glukozyd kwercetyny, 3-O-glukozyd kemferolu, zaś kwasy fenolowe reprezentowane są przez kwas kawowy, ferulowy, p-kumarowy, galusowy i p-hydroksybenzoesowy [18].

Nasiona porzeczki czarnej zawierają też polisacharydy o wysokiej masie cząsteczkowej. Wyizolowano galaktany o masie cząsteczkowej od ok. $10^{3} \mathrm{Da}$ do $340 \cdot 10^{3} \mathrm{Da}$, które in vitro hamowały adhezję Helicobacter pylori do błony śluzowej żołądka człowieka. Te polimery blokują receptory obecne na powierzchni komórek Helicobacter i w ten sposób uniemożliwiają bakteriom interakcję z błonami komórkowymi nabłonka żołądka [17]. Preparat zawierający polisacharydy uzyskane w wyniku trawienia nasion wpływał na przebieg alergii wywołanej przez cedr, podczas której obserwowano podwyższony poziom immunoglobuliny biorącej udział $\mathrm{w}$ reakcjach alergicznych IgE. Polisacharydy z nasion porzeczki łagodziły główny objaw alergii katar sienny, chociaż nie obserwowano zmniejszenia stężenia IgE [5].

\section{Liście porzeczki czarnej (Ribis nigri folium)}

Liście porzeczki czarnej są niedocenionym źródłem związków bioaktywnych o właściwościach przeciwutleniających. Liście zbierane w okresie dojrzałości, gdy osiągną typowy dla gatunku rozmiar, charakteryzują się największą zawartością związków fenolowych [28]. Profil związków fenolowych oznaczanych w liściach zależy od sposobu ekstrakcji, odmiany a nawet terminu zbioru liści. Zawartość związków fenolowych w acetonowych ekstraktach z liści była większa niż w ekstraktach z owoców porzeczki czarnej [28]. Według Nour i wsp. [20] najlepszym sposobem ich pozyskiwania jest wodny 40-procentowy roztwór alkoholu etylowego, w którym uzyskiwano całkowite stężenie związków fenolowych na poziomie $32 \div 44 \mathrm{mg} \cdot \mathrm{g}^{-1} \mathrm{~s} . \mathrm{m}$. Liście innych roślin jagodowych o znanych właściwościach terapeutycznych to: liście tru- 
skawki, które zawierały $30,9 \mathrm{mg} \cdot \mathrm{g}^{-1} \mathrm{~s} . \mathrm{m}$. związków fenolowych, liście jeżyny $48,5 \mathrm{mg} \cdot \mathrm{g}^{-1} \mathrm{~s} . \mathrm{m}$., liście malin $-54,7 \mathrm{mg} \cdot \mathrm{g}^{-1} \mathrm{~s} . \mathrm{m}$. [31]. Do głównych związków fenolowych wykrywanych w liściach należą: kwercetyna - średnio $1,359 \mathrm{mg} \cdot \mathrm{g}^{-1} \mathrm{~s} . \mathrm{m}$. ., mirycetyna $-0,831 \mathrm{mg} \cdot \mathrm{g}^{-1} \mathrm{~s} . \mathrm{m} .$, rutyna $-0,266 \mathrm{mg} \cdot \mathrm{g}^{-1} \mathrm{~s} . \mathrm{m}$. Kwasy fenolowe reprezentowane są głównie przez kwasy: salicylowy $-0,236 \mathrm{mg} \cdot \mathrm{g}^{-1} \mathrm{~s} . \mathrm{m} ., \mathrm{p}$-kumarowy $-0,285 \mathrm{mg} \cdot \mathrm{g}^{-}$ ${ }^{1}$ s.m., galusowy $-0,198 \mathrm{mg} \cdot \mathrm{g}^{-1} \mathrm{~s}$.m. oraz występujące w mniejszych stężeniach $(0,007$ $\div 0,088 \mathrm{mg} \cdot \mathrm{g}^{-1}$ s.m.) kwasy: chlorogenowy, synapinowy, ferulowy i kawowy [20]. Odnotowano znaczne różnice pod względem ilości kwasu chlorogenowego i kawowego w zależności od odmiany porzeczki [3]. Aktywność biologiczna mieszaniny flawonoidów uzyskiwanych z liści porzeczki jest wyższa niż aktywność jej dwu głównych składników, czyli rutyny i kwercetyny. Ekstrakty z liści ze względu na dużą zawartość związków fenolowych wykazują właściwości przeciwutleniające. Polifenole zawarte w ekstraktach z liści porzeczki czarnej działają ochronnie na erytrocyty [2]. Związki zawarte w ekstraktach roślinnych włączane są do obszaru hydrofilowego błony erytrocytu, zmieniają jej właściwości i zwiększają odporność na hemolizujący roztwór chlorku sodu [3]. Proantocyjanidyny z liści porzeczki czarnej hamują zapalenie opłucnej u szczurów [11]. Ekstrakt z liści porzeczki czarnej wykazywał działanie przeciwzapalne w badaniach modelowych obrzęku kończyny indukowanego karageniną u szczurów. Jego aktywność farmakologiczną porównywano z działaniem niesteroidowych leków przeciwzapalnych indometacyną lub kwasem niflumowym i, w przeciwieństwie do nich, nawet po długotrwałym stosowaniu nie powodował zmian krwotocznych [4]. Badano możliwość zastosowania ekstraktów polifenolowych z liści wiśni i czarnej porzeczki jako naturalnych środków przeciwdrobnoustrojowych w produktach mięsnych. Wyciąg z liści czarnej porzeczki i wiśni zwiększał trwałość wędlin pakowanych, wykazywał działanie przeciwutleniające, wpływał na podwyższenie jakości mikrobiologicznej kiełbas wieprzowych. Ekstrakty z liści wiśni były bardziej skuteczne niż z liści porzeczki, ale zawierały też 1,5 raza większe stężenie związków fenolowych [21]. Związki fenolowe, oprócz właściwości przeciwutleniających, wykazują szereg pozytywnych działań na organizm, jak m.in. działanie przeciwgrzybicze, przeciwbakteryjne i przeciwzapalne [2]. Niektóre związki polifenolowe i ekstrakty roślinne wykorzystuje się obecnie jako suplementy diety w profilaktyce lub jako leki w leczeniu chorób nowotworowych, układów krążenia, pokarmowego, moczowego, oddechowego oraz w dermatologii [12].

W liściach wykryto unikatowe kwasy thuszczowe: $\alpha$-linolenowy, kwas cis7,10,13-heksadekatrienowy (16:3), stearydynowy (18:4) i $\gamma$-linolenowy $(\gamma-18: 3)$ oraz fosfatydylocholinę i fosfatydyloglicerol. Frakcja galaktolipidów zawierała wyższe stężenie monogalaktozylodiacyloglicerolu niż digalaktozylodiacyloglicerolu. Związki te mają potencjalną aktywność przeciwnowotworową, przeciwzapalną i przeciwdrobnoustrojową [6]. 
Liście porzeczki czarnej zawierają znaczne ilości makro-, mikroelementów i pierwiastków śladowych, które pełnią istotną rolę w aktywacji enzymów i regulacji metabolizmu, wpływają na gospodarkę mineralną organizmu [13]. Liście są zasobne w wapń (średnio $11 \div 17 \mathrm{mg} \cdot \mathrm{g}^{-1} \mathrm{~s} . \mathrm{m}$.) i magnez $\left(5 \div 7,5 \mathrm{mg} \cdot \mathrm{g}^{-1} \mathrm{~s} . \mathrm{m}\right.$.) [20]. Zawartość potasu $\left(9 \div 15 \mathrm{mg} \cdot \mathrm{g}^{-1} \mathrm{~s} . \mathrm{m}\right.$. $)$ w stosunku do zawartości sodu $\left(0,012 \div 0,063 \mathrm{mg} \cdot \mathrm{g}^{-1} \mathrm{~s} . \mathrm{m}\right.$. $)$ jest duża [20], co jest korzystne dietetycznie i wyjaśnia moczopędne działanie naparów z liści. Spośród mikroelementów obecnych w liściach porzeczki czarnej występuje między innymi żelazo $\left(0,257 \div 0,433 \mathrm{mg} \cdot \mathrm{g}^{-1} \mathrm{~s} . \mathrm{m}\right.$. $)$, mangan $\left(0,041 \div 0,077 \mathrm{mg} \cdot \mathrm{g}^{-1} \mathrm{~s} . \mathrm{m}\right.$. $)$ i stosunkowo dużo boru $\left(0,041 \div 0,065 \mathrm{mg} \cdot \mathrm{g}^{-1} \mathrm{~s} . \mathrm{m}\right.$. $)[20]$.

Świeże liście porzeczki czarnej mają aromatyczny zapach za sprawą olejków eterycznych, suszone tracą zapach. $\mathrm{W}$ ich skład wchodzą głownie monoterpeny ( $\alpha$-pinen, myrcen, p-cymen, limonen, $\beta$-ocymen), seskwiterpeny - karyofylen i humulen, a także salicylan metylu [10]. Wyciąg z liści czarnej porzeczki w porównaniu z ekstraktami z pąków i jagód ma najwyższe zdolności przeciwutleniające i przeciwzapalne [28].

\section{Podsumowanie}

Znane w tradycyjnej medycynie właściwości pąków, nasion i liści w leczeniu niektórych chorób, jak przeziębienie, stan zapalny, cukrzyca, zaburzenia wzroku znalazły potwierdzenie we współczesnych badaniach. Naukowo udokumentowane właściwości pąków, nasion i liści, dotyczące ich składu i korzystnego wpływu na organizm, pozwalają uznać te surowce za alternatywne źródło składników bioaktywnych, jak przeciwutleniacze, nienasycone kwasy tłuszczowe i składniki mineralne. Owoce czarnej porzeczki są określane terminem superżywność ze względu na dużą zawartość bioaktywnych związków korzystnych dla zdrowia. Podobnym terminem - super surowców można określić pąki, liście i nasiona tej rośliny. Wykorzystanie pąków, nasion i liści jest szansą na zwiększenie opłacalności produkcji porzeczki czarnej, a dla konsumentów - na pozyskanie nowych źródeł substancji bioaktywnych. Owoce jagodowe są cennym surowcem przemysłowym. Spośród krajów Unii Europejskiej Polska jest wiodącym producentem soków zagęszczonych i mrożonek. W naszym kraju wielkość i opłacalność upraw porzeczki czarnej ulega znacznym wahaniom wynikającym z dużej niestabilności cen i podaży owoców. Tradycyjna i ekologiczna uprawa porzeczki czarnej może stać się bardziej opłacalna, gdy z plantacji będą pozyskiwane nasiona, pąki i liście. Hodowla odmian porzeczki czarnej ukierunkowana na zwiększenie zawartości wybranych składników bioaktywnych również sprzyjałaby upowszechnieniu liści, pąków i nasion jako surowca do produkcji leków i suplementów.

\section{Literatura}

[1] Bakowska-Barczak A.M., Schieber A., Kolodziejczyk P.: Characterization of Canadian black currant (Ribes nigrum L.) seed oils and residues. J. Agric. Food Chem., 2009, 57 (24), 11528-11536. 
[2] Bonarska-Kujawa D., Cyboran S., Żyłka R., Oszmiański J., Kleszczyńska H.: Biological activity of blackcurrant extracts (Ribes nigrum L.) in relation to erythrocyte membranes. Biomed. Res. Int., 2014, \#783059.

[3] Cyboran S., Bonarska-Kujawa D., Pruchnik H., Żyłka R., Oszmiański J., Kleszczyńska H.: Phenolic content and biological activity of extracts of blackcurrant fruit and leaves. Food Res. Int., 2014, 65 (A), 47-58

[4] Declume C.L.: Anti-inflammatory evaluation of a hydroalcoholic extract of black currant leaves (Ribes nigrum). J. Ethnopharmacol., 1989, (1-2), 91-98.

[5] Dejima K., Ohshima A., Yanai T., Yamamoto R., Takata R., Yoshikawa T.: Effects of polysaccharide derived from black currant on relieving clinical symptoms of Japanese cedar pollinosis: A randomized double-blind, placebo-controlled trial. Biosci. Biotechnol. Biochem., 2007, 71 (12), 30193025 .

[6] Dobson G.: Leaf lipids of Ribes nigrum: A plant containing 16:3, alpha-18:3, gamma-18:3 and 18:4 fatty acids. Biochem. Soc. Trans., 2000, 28 (6), 583-586.

[7] Donno D., Beccaro G.L., Cerutti A.K., Mellano M.G., Bounous G.: Bud extracts as new phytochemical source for herbal preparations - quality control and standardization by analytical fingerprint. In.: Phytochemicals - isolation, characterisation and role in human health. Eds. V. Rao, L.G. Rao. InTechOpen, London 2015, pp. 187-218.

[8] Dvaranauskaite A., Venskutonis P.R., Raynaud C., Talou T., Vi'kelis P., Sasnauskas A.: Variation in essential oil composition in buds of six black currant (Ribes nigrum L.) cultivars at various development phases. Food Chem., 2009, 114 (2), 671-679.

[9] Ethorđević B.S., Pljevljakušić D.S., Savikin K.P., Stević T.R., Bigović D.J.: Essential oil from black currant buds as chemotaxonomy marker and antimicrobial agent. Chem. Biodivers., 2014, 11 (8), 1228-1240.

[10] Ferlemi A.V., Lamari F.N.: Berry leaves: An alternative source of bioactive natural products of mutritional and medicinal value. Antioxidants, 2016, 5 (2), \#17.

[11] Garbacki N., Kinet M., Nusgens B., Desmecht D., Damas J.: Proanthocyanidins, from Ribes nigrum leaves, reduce endothelial adhesion molecules ICAM-1 and VCAM-1. J. Inflamm. Lond., 2005, 2, \#9.

[12] Goffman G.D., Galletti S.: Gamma-linolenic acid and tocopherol contents in the seed oil of 47 accessions from several rubes species. J. Agric. Food Chem., 2001, 49 (1), 349-354.

[13] Gopalan A., Reuben S.C., Ahmed S., Darvesh A.S., Hohmann J., Bishayee A.: The health benefits of blackcurrants. Food Funct., 2012, 3, 795-809.

[14] Gosh D., Mc Ghie T.K., Zhang J., Adaim A., Skinner M.: Effect of anthocyanins and other phenolics of boysenberry and blackcurrant as inhibitors of oxidative stress and damage to cellular DNA in SH-SY5Y and HL-60 cells. J. Sci. Food Agric., 2006, 86 (5), 678-686.

[15] Jurgiel-Małecka G., Buchwał A.: Charakterystyka składu chemicznego owoców porzeczki uprawianej w regionie Pomorza Zachodniego. Żywność. Nauka. Technologia. Jakość, 2016, 6 (109), 90-101.

[16] Kikas A., Kahu K., Arus L., Kaldmäe H., Rätsep R., Libek A.: Qualitative properties of the fruits of blackcurrant Ribes nigrum L. genotypes in conventional and organic cultivation. Proc. Latvian Acad. Sci., 2017, 71 (3), 190-197.

[17] Lengsfeld C., Deters A., Faller G., Hensel A.: High molecular weight polysaccharides from black currant seeds inhibit adhesion of Helicobacter pylori to human gastric mucosa. Planta Med., 2004, 70 (7), 620-626.

[18] Lu Y., Foo L.Y.: Polyphenolic constituents of blackcurrant seed residue. Food Chem., 2003, 80 (1), 71-76.

[19] Militaru A.V., Simedrea I., Alexoi I., Peev C., Bernad E., Toma C.C.: Plant extracts from meristematic tissues (foliar buds and shoots): Antioxidant and therapeutic action. Studia Universitatis "Vasile Goldiș", Seria Știinţele Vieții, 2010, 20 (3), 45-47.

[20] Nour F., Stampar F., Veberic R., Jakopic J.: Anthocyanins profile, total phenolics and antioxidant activity of black currant ethanolic extracts as influenced by genotype and ethanol concentration. Food Chem., 2013, 141 (2), 961-966. 
[21] Nowak A., Czyżowska A., Efenberger M., Krala L.: Polyphenolic extracts of cherry (Prunus cerasus L.) and blackcurrant (Ribes nigrum L.) leaves as natural preservatives in meat products. Food Microbiol., 2016, 59, 142-149.

[22] Olsson M.E., Gustavsson K.E., Andersson S., Nilsson A., Duan R.D.: Inhibition of cancer cell proliferation in vitro by fruit and berry extracts and correlations with antioxidant levels. J. Agric. Food Chem., 2004, 52 (24), 7264-7271.

[23] Pachołek B., Małecka M.: Pestki czarnej porzeczki jako źródło naturalnych przeciwutleniaczy. Rośliny Oleiste, 2000, XXI, 675-682.

[24] Raiciu A.D., Mihele D.E., Ionita C., Nistorica V., Manea S.: Antimicrobial activity of Ribes nigrum, Rosmarinus officinalis, Betula pubescens, Salix alba, Vaccinium mirtillus gemoderivatives. Farmacia, 2010, 58 (6), 735-747.

[25] Ruiz del Castillo M.L., Dobson G., Brennan R., Gordon S.: Genotypic variation in fatty acid content of blackcurrant seeds. J. Agric. Food Chem., 2002, 50 (2), 332-335.

[26] Ruiz del Castillo M.L., Dobson G., Brennan R., Gordon S.: Fatty acid content and juice characteristics in black currant (Ribes nigrum L.) genotypes. J. Agric. Food Chem., 2004, 52 (4), 948-952.

[27] Suzutani T., Ogasawara M., Yoshida I., Azuma M., Knox Y.M.: Anti-herpesvirus activity of an extract of Ribes nigrum L. Phytother. Res. 2003, 17 (6), 609-613.

[28] Tabart J., Kevers C., Evers D., Dommes J.: Ascorbic acid, phenolic acid, flavonoid, and carotenoid profiles of selected extracts from Ribes nigrum. J. Agric. Food Chem., 2011, 59 (9), 4763-4770.

[29] Tahvonen R.L., Schwab U.S., Linderborg K.M., Mykkänen H.M., Kallio H.P.: Black currant seed oil and fish oil supplements differ in their effects on fatty acid of plasma lipids, and concentrations of serum total and lipoprotein lipids, plasma glucose and insulin. J. Nutr. Biochem., 2005, 16 (6), 353-359.

[30] Vagiri M., Ekholm A., Öberg E., Johansson E., Andersson S., Rumpunen K.: Phenols and ascorbic acid in black currants (Ribes nigrum L.): Variation due to genotype, locations and year. J. Agric. Food Chem., 2013, 61 (39), 9298-9306.

[31] Wang S.Y., Lin H.S.: Antioxidant activity in fruits and leaves of blackberry, raspberry, and strawberry varies with cultivar and developmental stage. J. Agric. Food Chem., 2000, 48 (2), 140-146.

[32] Whelan J., Rust C.: Innovative dietary sources of n-3 fatty acids. Ann. Rev. Nutr., 2006, 26, 75-103.

[33] Yoshida K., Ohguro I., Ohguro H.: Black currant anthocyanins normalized abnormal levels of serum concentrations of endothelin-1 in patients with glaucoma. J. Ocul. Pharmacol. Ther., 2013, 29 (5), 480-487.

[34] Zmarlicki K., Brzozowski P.: Uwarunkowania w produkcji agrestu, czarnej porzeczki i borówki wysokiej. Wyd. Instytutu Ogrodnictwa, Skierniewice 2016, ss. 1-11.

\section{BUDS, LEAVES, AND SEEDS OF BLACKCURRANT - SOURCE OF BIOACTIVE SUBSTANCES WITH PRO-HEALTH PROPERTIES}

\section{S u m m a r y}

Blackcurrant is a plant cultivated for its tasty fruit eaten fresh and in a processed form. The blackcurrant fruit is a valuable diet component because of its high content of health-promoting compounds such as vitamin C, phenolic compounds, and minerals. Buds, leaves, and seeds of blackcurrant constitute a relatively unknown source of bioactive compounds with pro-health and medicinal properties. Traditional medicine utilizes buds, leaves and currant seeds to treat certain diseases. Contemporary scientific research confirms the beneficial effect of those underestimated parts of the blackcurrant plant. The main bioactive compounds contained in black currant buds are essential oils including hydrocarbons and terpenes. Bud oils are characterized by a strong antibacterial and antifungal activity. Another group of bioactive substances are phenolic compounds, mainly rutin, epicatechin, and kaempferol. Owing to those substances, the buds have antioxidant and anti-inflammatory properties. Oil made from seeds of black currant can be 
an excellent source of unsaturated fatty acids and tocopherols, especially $\alpha$-tocopherol. It also contains sterols known for the anti-atherosclerotic and anticancer activity. Black currant seed extracts contain large amounts of beneficial biologically active substances such as phenolic compounds and polysaccharides, mainly galactans. Owing to their high content of various phenolic compounds and essential oils, leaf extracts have antioxidant properties. Black currant leaves have a unique fatty acid composition with the potential anti-cancer, anti-inflammatory and antimicrobial activity. The potassium to sodium ratio in the leaves is high and this explains the diuretic effect of their infusions. The paper presents some application examples of the buds, seeds, and leaves. The objective of the study was to systematise the knowledge of the pro-health applications of extracts from those raw materials.

Key words: blackcurrant, buds, seeds, leaves, bioactive compounds 